\title{
ВПЛИВ ГОСТРОЇ КРОВОВТРАТИ ТА ІШЕМІЇ-РЕПЕРФУЗІЇ КІНЦІВКИ НА ГЕНЕРАЦІЮ АКТИВНИХ ФОРМ ОКСИГЕНУ ЛЕЙКОЦИТАМИ БРОНХОАЛЬВЕОЛЯРНОГО ЗМИВУ
}

\section{Вплив гострої крововтрати та ішемії-реперфузії кінцівки на генерацію активних форм оксигену лейкоцитами бронхоальвеолярного змиву \\ О. В. Стахів ${ }^{1}$, А. А. Гудима², М. І. Марущак ${ }^{2}$ \\ ТОВ «Клініка ендоскопічної та пластичної хірургії Стахіва» ${ }^{1}$ \\ Тернопільський національний медичний університет імені І. Я. Горбачевського МОЗ України ${ }^{2}$}

Резюме. Гостра крововтрата належить до ключових причин смертності за умов вогнепальних уражень. Ефрективним методом зупинки кровотечі на місці подіі $\epsilon$ застосування кровоспинного джгута з максимальним терміном ішемії кінцівки 2 год. Встановлено, що у реперфузійному періоді поглиблюються системні порушення в організмі, викликані масивною крововтратою. Однак зміни в легенях вивчені недостатньо.

Мета дослідження - з'ясувати вплив експериментальної гострої крововтрати, ускладненої ішемієюреперфузією кінцівки, на генерацію активних фрорм оксигену лейкоцитами бронхоальвеолярного змиву.

Матеріали і методи. Дослідження проведено на 216 білих нелінійних щурах-самцях масою 200-220 г. Усі експерименти виконані під тіопентал-натрієвим наркозом. У тварин моделювали ішемію-реперфузію кінцівки, гостру крововтрату та поєднували ці ушкодження. В окремій групі проводили корекцію виявлених порушень карбацетамом. Через 1 і 2 год, а також через 1, 7 і 14 діб у дослідних тварин визначали рівень активних фрорм оксигену в популяції лейкоцитів бронхоальвеолярного змиву.

Результати. За умов ішемії-реперфузії кінцівки, гострої крововтрати та їх поєднання у бронхоальвеолярному змиві зростає кількість лейкоцитів, які генерують активні форми оксигену. Моделювання лише ішемії-репердузії кінцівки супроводжується мінімальними порушеннями з максимумом через 2 год експерименту, які до 14 доби нормалізуються. Після моделювання гострої крововтрати та ії поєднання 3 ішемією-реперфузією кінцівки показник зростає хвилеподібно з двома періодами підвищення - через 1 добу ma 14 діб експерименту. Порушення істотно більші після одночасного моделювання гострої крововтрати та ішемії-реперфузії кінцівки. Застосування за цих умов карбацетаму нівелює виявлені порушення у всіх дослідних групах.

(c). В. Стахів та ін., 2020
Influence of acute blood loss and ischemiareperfusion of the limbs on the generation of active forms of oxygen by leukocytes of bronchoalveolar lavage

O. V. Stakhiv' ${ }^{1}$ A. A. Hudyma², M. I. Marushchak ${ }^{2}$

Stakhiv Endoscopic and Plastic Surgery Clinic ${ }^{1}$

I. Horbachevsky Ternopil National Medical University²

e-mail: arsgudyma@gmail.com

Summary. Acute blood loss is one of the key causes of death from gunshot wounds. An effective method of stopping bleeding at the scene is the use of a tourniquet with a maximum limb ischemia of 2 hours. It was established that in the reperfusion period the systemic disturbances in an organism caused by massive blood loss deepen. However, changes in the lungs were not studied enough.

The aim of the study - to determine the effect of experimental acute blood loss complicated by ischemiareperfusion of the limb on the generation of reactive oxygen species by leukocytes of the bronchoalveolar lavage.

Materials and Methods. The study was performed on 216 white nonlinear male rats weighing 200-220 g. All experiments were performed under thiopental-sodium anesthesia. In animals, limb ischemia-reperfusion and acute blood loss were simulated and these lesions were combined. In a separate group, the detected disorders were corrected with carbacetam. After 1 and 2 hours, as well as after 1, 7 and 14 days in experimental animals, the level of reactive oxygen species in the population of leukocytes of bronchoalveolar lavage was determined.

Results. Under conditions of ischemia-reperfusion of the limb, acute blood loss and their combination in the bronchoalveolar lavage increases the number of leukocytes that generate reactive oxygen species. Simulation of limb ischemia-reperfusion only is accompanied by minimal disturbances with a maximum after $2 \mathrm{~h}$ of the experiment, which are normalized by 14 days. After modeling acute blood loss and its combination with ischemia-reperfusion of the limb, the rate increases in waves with two periods of increase - after 1 day and 14 days of the experiment. Violations are significantly greater after simultaneous simulation of acute blood loss and ischemia-reperfusion of the limb. The use of carbacetam under these conditions eliminates the identified violations in all experimental groups. 
Висновки. За умов ішемії-реперфузії кінцівки, гострої крововтрати та їх поєднання у бронхоальвеолярному змиві зростає кількість лейкоцитів, які генерують АФО. Унаслідок одночасного моделювання гострої крововтрати та ішемії-реперфрузії кінцівки порушення $є$ більшими. Застосування карбацетаму через 7-14 діб знижує інтенсивність утворення активних фрорм оксигену лейкоцитами бронхоальвеолярного змиву в усіх дослідних групах, що вказує на перспективність засобу для корекції виявлених порушень.

Ключові слова: гостра крововтрата; ішемія-реперфузія кінцівки; активні форми оксигену; лейкоцити; бронхоальвеолярний змив; карбацетам.

\section{ВСТУП}

Гостра крововтрата належить до основних причин загибелі організму за умов застосування вогнепальної зброї та вибухових пристроїв. Збільшення частоти терористичних атак і локальних збройних конфрліктів, а відтак зростання числа поранених з ушкодженням магістральних судин кінцівок спонукали до пошуку ефективних засобів боротьби 3 масивною кровотечею [1]. Загальновизнано, що своєчасне накладання джгута, який повністю припиняє артеріальний кровотік, належить до ефективних засобів зупинки масивної зовнішньої кровотечі 3 кінцівок. Максимально допустимий час ішемії кінцівки до відновлення кровотоку становить 2 год [2].

Останнім часом з'явилося ряд експериментальних робіт, в яких показано, що двогодинне повне знекровлення кінцівки зумовлює системні порушення в організмі, викликані надходженням у кровотік токсичних метаболітів з ішемізованої кінцівки після її реперфузії [3]. Однак ці процеси значно поглиблюються після одночасного моделювання ішемії-реперорузії кінцівки та гострої крововтрати. За цих умов окремі автори відмічають порушення фрункціонального стану внутрішніх органів [4], зокрема нирок [5] та печінки [6].

Не менш чутливими до гострої крововтрати та ендотоксикозу різної етіології є легені. За цих умов може виникати ушкодження альвеолокапілярної мембрани з підвищенням проникності легеневих капілярів та розвитком набряку легень [7]. Пусковим моментом цих порушень лежить виділення прозапальних медіаторів, які активізують нейтрофріли, що накопичуються в паренхімі легень, з вивільненням цитоплазматичних гранул (протеаз та метаболітів кисню).

Метою дослідження було з'ясувати вплив експериментальної гострої крововтрати, ускладненої ішемією-реперфузією кінцівки, на генерацію активних фрорм оксигену лейкоцитами бронхоальвеолярного змиву.
Conclusions. Under conditions of ischemia-reperfusion of the limb, acute blood loss and their combination in the bronchoalveolar lavage increases the number of leukocytes that generate AFO. Due to the simultaneous simulation of acute blood loss and ischemia-reperfusion, limb disorders are greater. The use of carbacetam after 7-14 days reduces the intensity of the formation of reactive oxygen species by leukocytes of the bronchoalveolar lavage in all experimental groups, which indicates the prospects of the tool for the correction of detected disorders.

Key words: acute blood loss; ischemia-reperfusion of the limb; reactive oxygen species; leukocytes; bronchoalveolar lavage; carbonate.

\section{МАТЕРІАЛИ I МЕТОДИ}

Дослідження проведено на 216 білих нелінійних щурах-самцях віком 6-8 місяців масою 200220 г, яких утримували в одному приміщенні при постійній температурі 18-22 ${ }^{\circ} \mathrm{C}$ на стандартному режимі віварію. Усі експерименти виконано 3 дотриманням норм Конвенції Ради Європи про захист хребетних тварин, що використовуються для досліджень та інших наукових цілей (Страсбург, 1986), ухвали Першого національного конгресу 3 біоетики (Київ, 2001) і Наказу МОЗ України № 690 від 23.09.2009 р. Комісія з питань біоетики Тернопільського національного медичного університету імені І. Я. Горбачевського МОЗ України порушень морально-етичних норм при проведенні науководослідної роботи не виявила.

Усі експерименти виконані під тіопентал-натрієвим наркозом (40 мг/кг). Усіх тварин поділили на п'ять груп: контрольну (6 щурів) та чотири дослідних. У першій дослідній групі (50 щурів) тваринам моделювали ішемію-реперфузію кінцівки шляхом накладання проксимально на ліву лапку смужку еластичного джгута «SWAT-T» (США) шириною 10 мм на 120 хв [5]. У другій дослідній групі (50 щурів) моделювали гостру крововтрату (20 \% від об'єму циркулюючої крові) шляхом пересікання стегнової вени. У третій дослідній групі ці ушкодження поєднували (50 щурів). У четвертій дослідній групі тваринам з ішемієюреперфузією кінцівки (20 щурів), з гострою крововтратою (20 щурів) та їх поєднанням (20 щурів) внутрішньочеревно вводили карбацетам (Інститут фрізико-органічної хімії та вуглехімії НАН України, Донецьк) в дозі 5 мг на кілограм маси тварини [3]. В контрольній групі тварин тільки вводили в наркоз і в подальшому брали для досліджень через 3 год.

Через 1 і 2 год, а також через 1, 7 і 14 діб дослідних тварин першої, другої і третьої груп, а також через 7 і 14 діб дослідних тварин четвертої групи виводили з експерименту методом тотального кровопускання з серця. Для досліджень брали бронхоальвеолярний змив, у якому визначали рівень активних орорм оксигену (АФО) у популяції 
лейкоцитів. Застосовували барвник із заблокованою фрлюоресценцією - дигідродихлорфлюоресцеїну диацетату («Sigma Aldrich», USA) методом проточної лазерної цитофрлуориметрії [8]. Аналіз зразків клітин проводили на проточному цитометрі Epics XL («Beckman Coulter», США) за допомогою гістограм та відповідних їм вікон статистики, що містили показники середньої геометричної інтенсивності світіння мічених клітин.

Значення досліджуваного параметра виражали у відсотках (співвідношення числа лейкоцитів із підвищеним внутрішньоклітинним вмістом АФО до загальної кількості клітин).

Оцінку вірогідності відмінностей між експериментальними групами проводили з використанням непараметричного критерію Манна-Уїтні.

\section{РЕЗУЛЬТАТИ Й ОБГОВОРЕННЯ}

Ми встановили, що в усіх дослідних групах у бронхоальвеолярному змиві, порівняно 3 контрольною групою, зростала генерація АФО. Так, у тварин, яким моделювали ішемію-репердузію кінцівки вміст лейкоцитів-продуцентів АФО вірогідно зріс, порівняно з контрольною групою, через 1 год - у 2,0 рази, через 2 год - в 2,3 раза, через 1 добу - в 1,8 раза і через 7 діб - у 1,6 раза $(p<0,05)$. Варто відмітити, що через 14 діб репердузійного періоду показник практично не відрізнявся від даних контрольної групи ( $>>0,05)$.

При порівнянні вмісту лейкоцитів-продуцентів АФО у різні терміни реперфузійного періоду в межaх групи, в якій моделювали лише ішемію-реперфузію кінцівки, встановлено, що максимальний рівень показника досягав через 2 год експерименту.
В цей термін показник був на 14,9 \% вищим стосовно даних 1 год експерименту, на 32,5\%, порівняно $з 1$ добою, на 42,3 \%, порівняно $з 7$ добою, та на 136,9 \% порівняно 314 добою ( $<<0,05)$.

У тварин, яким моделювали крововтрату, вміст клітин - продуцентів АФО лейкоцитарного змиву стосовно контролю збільшився через 1 год у 2,1 раза, через 2 год - в 2,5 раза, через 1 добу - в 3,8 раза, через 7 діб - в 3,4 раза і через 14 діб - в 3,7 раза ( $p<0,05)$. Максимальну генерацію АФО відмічали через 1 і 14 діб після експериментальної крововтрати. Варто відмітити, що рівень продукції АФО лейкоцитами бронхоальвеолярного змиву через 7 діб експерименту був вірогідно нижчий порівняно $з 1$ добою (на 12,6 \%, р<0,05) і 14 добою (на 10,5\%, р<0,05).

У щурів після гострої крововтрати, ускладненої ішемією-реперорузією кінцівки, рівень продукції АФО вірогідно зріс через 1 год в 3,3 раза, через 2 год - у 3,9 раза, через 1 добу - в 4,3 раза, через 7 діб - у 3,7 раза і через 14 діб - в 4,7 раза стосовно контрольної групи ( $<<0,05)$. При зіставленні отриманих результатів рівня АФО в різні терміни реперфруійного періоду в межах однієї групи спостерігали максимальну генерацію АФО через 1 і 14 діб експерименту. Варто відмітити, що рівень продукції АФО лейкоцитами бронхоальвеолярного змиву через 7 діб експерименту був вірогідно нижчий від даних через 1 добу (на 18,0 \%, р<0,05) і 14 діб (на 27,4 \%, р<0,05) (табл. 1, рис.).

При зіставленні отриманих показників АФО у різних групах встановлено однонаправлені зміни досліджуваного показника в тварин другої і третьої дослідних груп. При цьому генерація АФО зроста-

Таблиця 1. Генерація активних фрорм оксигену лейкоцитами бронхоальвеолярного змиву (\%) у щурів після гострої крововтрати, ускладненої ішемією-реперсрузією кінцівки (Ме (Q25; Q75))

\begin{tabular}{|c|c|c|c|c|c|}
\hline \multirow{2}{*}{ Дослідна група } & \multicolumn{5}{|c|}{ Термін реперфузійного періоду } \\
\hline & 1 год & 2 год & 1 доба & 7 доба & 14 доба \\
\hline \multicolumn{6}{|c|}{ Контроль = 18,2 $(16,3 ; 19,5)(n=6)$} \\
\hline $\begin{array}{l}\text { Перша } \\
\text { Ішемія-реперфузія }\end{array}$ & $\begin{array}{c}36,9^{*} \\
(33,2 ; 40,8) \\
(n=10)\end{array}$ & $\begin{array}{c}42,4^{*} \\
(31,9 ; 47,0) \\
(n=10)\end{array}$ & $\begin{array}{c}32,0^{\star} \\
(29,7 ; 34,9) \\
(n=10)\end{array}$ & $\begin{array}{c}29,8^{\star} \\
(24,9 ; 31,2) \\
(n=10)\end{array}$ & $\begin{array}{c}17,9 \\
(17,0 ; 19,4) \\
(n=10)\end{array}$ \\
\hline$p_{1-2}$ & $>$ & $>0,05$ & $<0,05$ & $<0,05$ & $<0,05$ \\
\hline $\begin{array}{l}\text { Друга } \\
\text { Крововтрата }\end{array}$ & $\begin{array}{c}38,2^{*} \\
(35,8 ; 40,3) \\
(n=10)\end{array}$ & $\begin{array}{c}48,4^{*} \\
(40,0 ; 51,7) \\
(n=10)\end{array}$ & $\begin{array}{c}68,9^{\star} \\
(67,2 ; 70,6) \\
(n=9)\end{array}$ & $\begin{array}{c}61,2^{\star} \\
(59,8 ; 65,9) \\
(n=8)\end{array}$ & $\begin{array}{c}67,6^{\star} \\
(65,6 ; 70,8) \\
(n=8)\end{array}$ \\
\hline$p_{2-3}$ & $<0,05$ & $<0,05$ & $<0,05$ & $>0,05$ & $<0,05$ \\
\hline $\begin{array}{l}\text { Tретя } \\
\text { Ішемія-реперфузія+ } \\
\text { крововтрата }\end{array}$ & $\begin{array}{c}59,6^{*} \\
(55,4 ; 61,9) \\
(n=10) \\
\end{array}$ & $\begin{array}{c}70,7^{\star} \\
(68,9 ; 71,7) \\
(n=10)\end{array}$ & $\begin{array}{c}78,8^{*} \\
(75,0 ; 84,3) \\
(n=8) \\
\end{array}$ & $\begin{array}{c}66,8^{*} \\
(59,6 ; 76,4) \\
(n=8) \\
\end{array}$ & $\begin{array}{c}85,1^{*} \\
(79,4 ; 86,6) \\
(n=8) \\
\end{array}$ \\
\hline $\mathrm{p}_{1-3}$ & $<0,05$ & $<0,05$ & $<0,05$ & $<0,05$ & $<0,05$ \\
\hline
\end{tabular}

Примітки: 1) * - відмінності стосовно контрольної групи статистично вірогідні $(p<0,05)$;

2) $\mathrm{p}_{1-2}$ - вірогідність відмінностей між першою і другою дослідними групами;

3) $\mathrm{p}_{2-3}$ - вірогідність відмінностей між другою і третьою дослідними групами;

4) $p_{1-3}$ - вірогідність відмінностей між першою і третьою дослідними групами. 


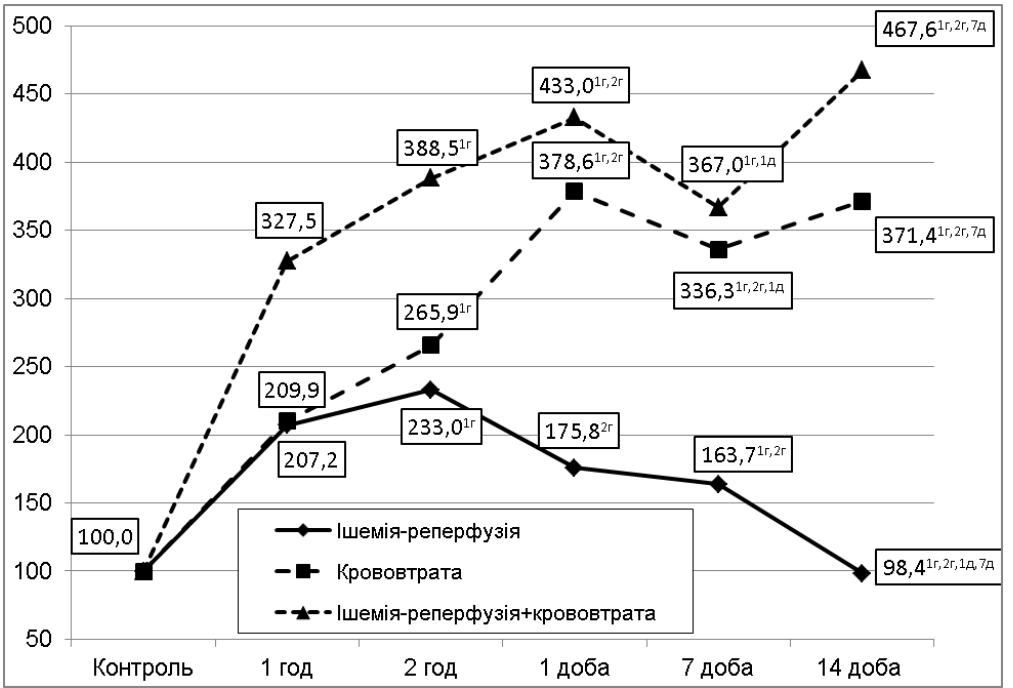

Рис. Динаміка вмісту генеруючих активні форми оксигену лейкоцитів бронхоальвеолярного змиву (у відсотках до рівня контролю) у щурів після гострої крововтрати, ускладненої ішемією-реперфузією кінцівки.

Примітка. 1г,2г,1д,7д - відмінності стосовно відповідно 1 і 2 год, а також 1 і 7 діб експерименту статистично вірогідні, р<0,05.

ла до 1 доби, потім через 7 діб відмічали статистично значуще зниження продукції кисневих радикалів з наступним їх підвищенням через 14 діб. У тварин першої групи, порівняно з іншими дослідними групами, продукція АФО до кінця терміну спостереження стабілізувалась. Варто відмітити, що найвище значення АФО спостерігали у бронхоальвеолярному змиві після гострої крововтрати, ускладненої ішемією-реперфузією кінцівки у всі терміни реперфузійного періоду $\left(p_{1-3}<0,05\right)$.

Дослідження АФО за умов корекції карбацетамом показало позитивну їх динаміку в усіх дослід- них групах (табл. 2). Так, у тварин, яким моделювали ішемію-реперфуузію та проводили корекцію карбацетамом, рівень АФО через 7 діб був вірогідно нижчий на 33,1 \% стосовно дослідної групи тварин без корекції $(p<0,05)$. Варто відмітити, що через 14 діб реперфузійного періоду рівень генерації АФО лейкоцитами бронхоальвеолярного змиву практично не відрізнявся від даних контрольної групи і не залежав від коригувального чинника.

У другій дослідній групі рівень генерації АФО лейкоцитами бронхоальвеолярного змиву за умов корекції через 7 діб був вірогідно нижчим на 16,0%

Таблиця 2. Генерація активних форм оксигену лейкоцитами бронхоальвеолярного змиву (\%) у щурів після гострої крововтрати, ускладненої ішемією-реперфузією кінцівки за умови корекції карбацетамом $\left(\mathrm{Me}\left(\mathrm{Q}_{25} ; \mathrm{Q}_{75}\right)\right)$

\begin{tabular}{|c|c|c|c|c|}
\hline \multirow{3}{*}{ Дослідна група } & \multicolumn{4}{|c|}{ Термін реперфузійного періоду } \\
\hline & \multicolumn{2}{|c|}{ без корекції } & \multicolumn{2}{|c|}{ корекція карбацетамом } \\
\hline & 7 доба & 14 доба & 7 доба & 14 доба \\
\hline \multicolumn{5}{|c|}{ Контроль $=18,2(16,3 ; 19,5)(n=6)$} \\
\hline $\begin{array}{l}\text { Перша } \\
\text { Ішемія-реперфузія }\end{array}$ & $\begin{array}{c}29,8^{*} \\
(24,9 ; 31,2) \\
(n=10)\end{array}$ & $\begin{array}{c}17,9 \\
(17,0 ; 19,4) \\
(n=10)\end{array}$ & $\begin{array}{c}19,5^{\#} \\
(17,0 ; 20,4) \\
(n=10)\end{array}$ & $\begin{array}{c}18,0 \\
(17,0 ; 19,3) \\
(n=10)\end{array}$ \\
\hline$p_{1-2}$ & $<0,05$ & $<0,05$ & $<0,05$ & $<0,05$ \\
\hline $\begin{array}{l}\text { Друга } \\
\text { Крововтрата }\end{array}$ & $\begin{array}{c}61,2^{*} \\
(59,8 ; 65,9) \\
(n=8)\end{array}$ & $\begin{array}{c}67,6^{*} \\
(65,6 ; 70,8) \\
(n=8)\end{array}$ & $\begin{array}{c}51,4^{\star \#} \\
(48,8 ; 53,9) \\
(n=10)\end{array}$ & $\begin{array}{c}39,2^{* \#} \\
(36,2 ; 41,1) \\
(n=10)\end{array}$ \\
\hline$p_{2-3}$ & $>0,05$ & $<0,05$ & $>0,05$ & $>0,05$ \\
\hline $\begin{array}{l}\text { Третя } \\
\text { Ішемія-реперфузія+ } \\
\text { крововтрата } \\
\end{array}$ & $\begin{array}{c}66,8^{*} \\
(59,6 ; 76,4) \\
(n=8)\end{array}$ & $\begin{array}{c}85,1^{*} \\
(79,4 ; 86,6) \\
(n=8) \\
\end{array}$ & $\begin{array}{c}53,7^{\star \#} \\
(51,7 ; 54,6) \\
(n=9)\end{array}$ & $\begin{array}{c}42,5^{\star \#} \\
(38,9 ; 45,6) \\
(n=9)\end{array}$ \\
\hline $\mathrm{p}_{1-3}$ & $<0,05$ & $<0,05$ & $<0,05$ & $<0,05$ \\
\hline
\end{tabular}

Примітки: 1) * - відмінності стосовно контрольної групи статистично вірогідні $(p<0,05)$;

2) $\mathrm{p}_{1-2}$ - вірогідність відмінностей між першою і другою дослідними групами;

3) $\mathrm{p}_{2-3}$ - вірогідність відмінностей між другою і третьою дослідними групами;

4) $\mathrm{p}_{1-3}^{2-3}$ - вірогідність відмінностей між першою і третьою дослідними групами;

5) \# - вірогідність відмінностей порівняно з тваринами без корекції в межах однієї групи статистично віргідні $($ р<0,05). 
$(p<0,05)$ і через 14 діб - на 42,0 \% стосовно даних у ці ж терміни без корекції $(p<0,05)$. При цьому в обидва терміни реперфузійного періоду рівень генерації АФО у щурів після гострої крововтрати за умови корекції карбацетамом був вірогідно вищий, ніж у контрольній групі $(p<0,05)$.

У третій дослідній групі рівень генерації АФО лейкоцитами бронхоальвеолярного змиву за умов корекції через 7 діб був вірогідно нижчим на 19,6 \% і через 14 діб - на 50,1 \% стосовно даних у ці ж терміни без корекції $(p<0,05)$, проте залишався статистично значимо вищим даних контрольної групи $(p<0,05)$.

Таким чином, за умов ішемії-реперорузї кінцівки, гострої крововтрати та їх поєднання у бронхоальвеолярному змиві зростає кількість лейкоцитів, які генерують АФО. Моделювання лише ішемії-реперфузії кінцівки супроводжується мінімальними порушеннями 3 максимумом через 2 год експерименту, які до 14 доби нормалізуються. Після моделювання гострої крововтрати та її поєднання з ішемією-реперфузією кінцівки показник зростає хвилеподібно з двома періодами підвищення - через 1 добу та 14 діб експерименту. Порушення істотно більші після одночасного моделювання гострої крововтрати та ішемії-реперфузії кінцівки.

Відомо, що зростання числа лейкоцитів у бронхоальвеолярному змиві, здатних генерувати АФО, зумовлене накопиченням прозапальних медіаторів, зокрема цитокінів [7]. У зв'язку з цим можна припустити, що гостра крововтрата, ускладнена ішемією-реперорузією кінцівки, супроводжується системною реакцією організму на запалення, що в подальшому може сприяти розвитку поліорганної недостатності. 3 іншого боку, посилення генерації АФО лейкоцитами легень сприяє посиленню ураження паренхіми органа, що може лежати в основі виникнення гострого ураження легень [9]. У свою чергу, розвиток легеневої недостатності замикає чергове «хибне» патологічне коло, поглиблюючи гіпоксемію, зумовлену гострою крововтратою та системну відповідь організму на запалення.

Застосування за цих умов карбацетаму нівелює виявлені порушення у всіх дослідних групах. Отже, фрункціональні групи препарату здатні знизити системні прояви порушень, зумовлені токсичними метаболітами ішемізованої кінцівки після ії реперфузії. Отриманий фракт підтверджує анало-

\section{СПИСОК ЛІТЕРАТУРИ}

1. Elster E. A. Implications of combat casualty care for mass casualty events / E. A. Elster, K. B. Frank, E. R. Todd // JAMA. - 2013. - Vol. 310 (5). - P. 475-476.

2. Efficacy of prehospital application of tourniquets and hemostatic dressings to control traumatic external hemorrhage. - Access mode : https://www.ems.gov/pdf/ гічні дослідження інших авторів щодо зниження карбацетамом тяжкості вторинного ураження печінки і нирок за умов гострої крововтрати, ускладненої ішемією-реперсузією кінцівки $[5,6]$.

Таким чином, надходження у системний кровотік токсичних метаболітів, зумовлених двогодинною ішемією кінцівки, та тих, що утворюються унаслідок її реперфузії, здатні поглиблювати негативні прояви гострої крововтрати, зокрема стимулювати розвиток гострого ураження легень, що необхідно враховувати у клініці при лікуванні поранених із гострою крововтратою та репефузією кінцівки через 2 год після її турнікетної ішемії.

За умов застосування карбацетаму в тварин із гострою крововтратою, ускладненою ішемією-реперфузією кінцівки, інтенсивність генерації АФО лейкоцитами легень суттєво знижується порівняно 3 тваринами без корекції. Хоча показник не досягав рівня контрольних тварин, карабцетам $€$ перспективним препаратом для корекції постішемічних i реперорузійних уражень, що вимагає подальшого доклінічного вичення.

У подальшому доцільно розширити спектр дослідження позитивного впливу карбацетаму на легені за умов гострої крововтрати, ускладненої ішемією-репердузією кінцівки.

\section{ВИСНОВКИ}

1. За умов ішемії-реперфузії кінцівки, гострої крововтрати та їх поєднання у бронхоальвеолярному змиві зростає кількість лейкоцитів, які генерують АФО. Моделювання лише ішемії-реперфузії кінцівки супроводжується мінімальними порушеннями 3 максимумом через 2 год експерименту, які до 14 доби нормалізуються. Після моделювання гострої крововтрати та її поєднання з ішемією-реперфузією кінцівки показник зростає хвилеподібно з двома періодами підвищення - через 1 добу та 14 діб експерименту. Порушення істотно більші після одночасного моделювання гострої крововтрати та ішемії-реперфузії кінцівки, що є наслідком взаємного обтяження обох патологічних процесів.

2. Застосування карбацетаму через 7-14 діб знижує інтенсивність утворення АФО лейкоцитами бронхоальвеолярного змиву в тварин, яким моделювали ішемію-реперфузію кінцівки, гостру крововтрату та їх поєднання, що вказує на перспективність засобу для корекції виявлених порушень.

research/Studies-and-Reports/Prehospital_Applications_ Of_Tourniquest_And_Hemostatic_Dressings.pdf.

3. Телев'як А. Т. Динаміка показників перекисного окислення ліпідів та антиоксидантного захисту в м'язовій тканині задніх кінцівок щурів при розвитку ішемічно-реперфузійного синдрому (експериментальне до- 
слідження) / А. Т. Телев'як // Здобутки клінічної і експериментальної медицини. - 2018. - № 3. - С. 132-139.

4. Volotovska N. V. Changes in the glutathione system's activity of internal organs in the first hours of experimental limb ischemia-reperfusion syndrome, combined with blood loss and mechanical injury / N. V. Volotovska, T. Nhokwara Cliff, I. V. Zhulkevych // Здобутки клінічної і експериментальної медицини. - 2019. - № 1. - Р. 17-23.

5. Шацький В. В. Вплив експериментальної гострої крововтрати, ускладненої ішемією-реперфузією кінцівки, на діурез і швидкість клубочкової фрільтрації / В. В. Шацький, А. А. Гудима, Р. В. Близнюк // Шпитальна хірургія. Журнал імені Л. Я. Ковальчука. - 2019. - № 4. - C. 50-58.

6. Peculiarities of impairments of absorptive-excretory and glycogen synthesis functions of the liver in the

\section{REFERENCES}

1. Elster EA, Frank KB, Todd ER. Implications of combat casualty care for mass casualty events. JAMA. 2013;310(5): 475-6.

2. Efficacy of prehospital application of tourniquets and hemostatic dressings to control traumatic external hemorrhage. Available from: https://www.ems.gov/pdf/ research/Studies-and-Reports/Prehospital_Applications Of_Tourniquest_And_Hemostatic_Dressings.pdf.

3. Televiak AT. [The dynamic of indicators of lipid peroxidation and antioxidant protection in muscle tissue of the hind limbs of the rats in development of the ischemicreperfusion syndrome (experimental study)]. Zdobutky klinichnoi I eksperymentalnoi medytsyny. 2018;3: 132-9. Ukrainian.

4. Volotovska NV, Cliff Nhokwara T, Zhulkevych IV. Changes in the glutathione systems activity of internal organs in the first hours of experimental limb ischemiareperfusion syndrome, combined with blood loss and mechanical injury. Zdobutky klinichnoi i eksperymentalnoi medytsy. 2019;1: 17-23. presence of acute blood loss complicated by limb ischemiareperfusion and their correction by carbacetam / I. I. Horban, A. A. Hudyma, R. V. Maksymiv, N. A. Dzhavadova // Journal of Education, Health and Sport. - 2020. - Vol. 10 (5). P. 301-314.

7. Abraham E. Neutrophils and acute lung injury / E. Abraham // Critical Care Medicine. - 2003. - Vol. 31, No. 4. - P. 195-199.

8. 7. Flow cytometric studies of oxidative product formation by neutrophils: a graded response to membrane stimulation / D. A. Bass, J. W. Parce, L. R. Dechatelet [et al.] // J. Immunol. - 1983. - Vol. 130. - P. 1910-1917.

9. Марущак М. І. Мітохондріальні механізми апоптозу при гострому ушкодженні легень в експерименті / М. І. Марущак // Вісник наукових досліджень. - 2017. № 1. - C. 121-124.

5. Shatsky VV, Hudyma AA, Blyzniuk RV. [Influence of experimental acute blood loss complicated by ischemiareperfusion of the extremity on the size of diuresis and the glomerular filtration rate]. Shpytalna khirurhiia. Zhurnal imeni L.Ya. Kovalchuka. 2019;4: 50-8. Ukrainian.

6. Horban II, HudymaAA, Maksymiv RV, DzhavadovaNA. Peculiarities of impairments of absorptive-excretory and glycogen synthesis functions of the liver in the presence of acute blood loss complicated by limb ischemia-reperfusion and their correction by carbacetam. Journal of Education, Health and Sport. 2020;10(5): 301-14.

7. Abraham E. Neutrophils and acute lung injury. Critical Care Medicine. 2003;31;4: 195-99.

8. BassDA, ParceJW, DechateletLR, SzejdaP,SeedsMC, Thomas M. Flow cytometric studies of oxidative product formation by neutrophils: a graded response to membrane stimulation. J. Immunol. 1983;130: 1910-17.

9. Marushchak MI. [Mitochondrial apoptosis mechanisms in experimental acute lung injury]. Visnyk naukovykh doslidzhen. 2017;1: 121-4. Ukrainian. 